Vol. 6, No. 1 Januari - Juni 2017

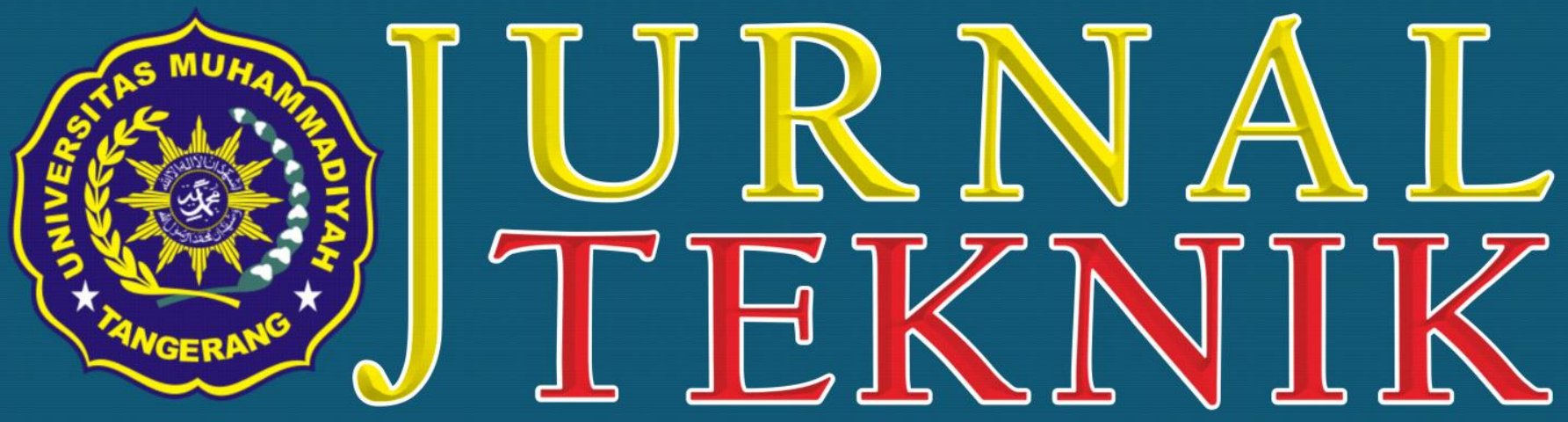

Alamat Redaksi: Jl. Perintis Kemerdekaan I No. 33, Cikokol Tangerang - TIp. (021) 51374916

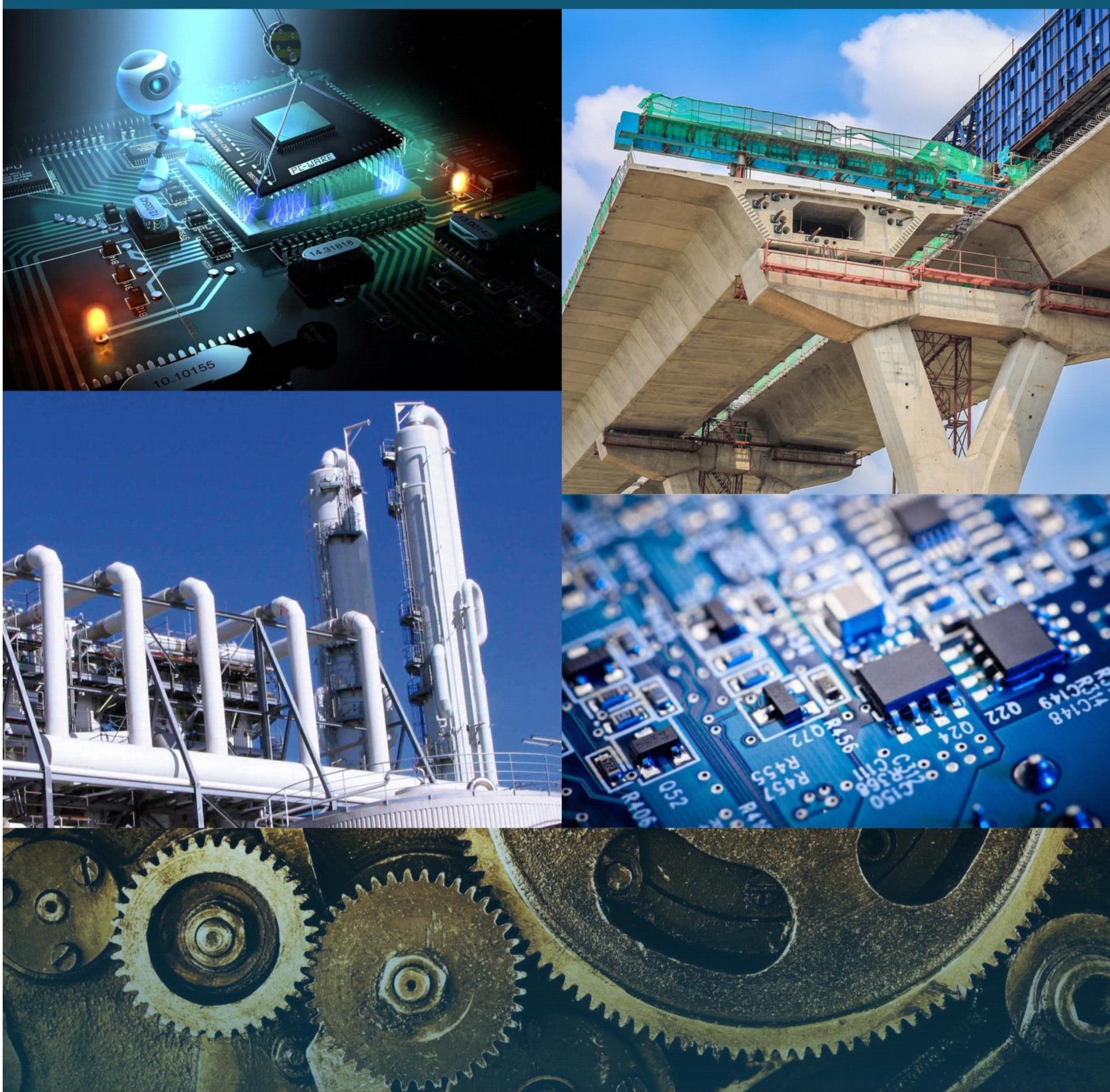




\section{J U R N A L TEKN I K}

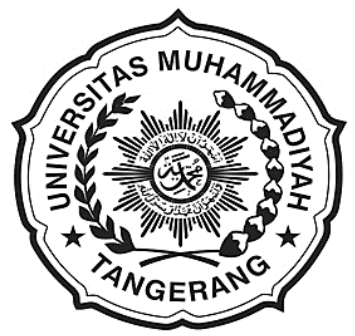

\section{UNIVERSITAS MUHAMMADIYAH TANGERANG}

Pelindung:

Dr. H. Achmad Badawi, S.Pd., SE., MM. (Rektor Universitas Muhammadiyah Tangerang)

Penanggung Jawab:

Ir. Saiful Haq, ST., M.Si.

(Dekan Fakultas Teknik)

Pembina Redaksi:

Rohmat Taufik, ST., M.Kom.

Drs. H. Syamsul Bahri, MSi.

Pimpinan Redaksi:

Ir. Sumardi Sadi, S.Pd., ST., MT.

Redaktur Pelaksana:

Yafid Efendi, ST, MT.

Editor Jurnal Teknik UMT:

Ir. Sumardi Sadi, S.Pd., ST., MT.

Dewan Redaksi:

Ir. Ali Rosyidin, ST., MM., MT.

Tri Widodo, ST.,MT.

Tina Herawati, ST., MT

Almufid, ST., MT.

Siti Abadiah, ST., MT.

M. Jonni, SKom., MKom.

Syepry Maulana Husain, S.Kom., M.Kom.

Ir. H. Bayu Purnomo, ST., MT

Kasubag:

Ferry Hermawan, MM.

Keuangan:

Elya Kumalasari, S.Ikom.

Setting \& Lay Out:

Muhlis, S.E

Saiful Alam, SE.

Mitra Bestari:

Prof. Dr. Aris Gumilar

Ir. Doddy Hermiyono, DEA

Dr. Ir. Budiyanto, MT.

Dr. Alimuddin, ST., MM., MT

J U R N A L T E K N I K

Diterbitkan Oleh:

Fakultas Teknik Universitas Muhammadiyah Tangerang

Alamat Redaksi:

Jl. Perintis Kemerdekaan I No. 33, Cikokol Tangerang Tlp. (021) 51374916

\begin{tabular}{|c|c|c|c|c|c|}
\hline \multirow{2}{*}{$\begin{array}{c}\text { Jurnal } \\
\text { Teknik }\end{array}$} & 6 & 1 & $1-97$ & $\begin{array}{c}\text { Jan'-Juni } \\
2017\end{array}$ & ISSN \\
\cline { 2 - 6 } & $2302-8734$ \\
\hline
\end{tabular}

\section{DAFTAR ISI}

1. PROSES PEMBUATAN ALAT PEMBUKA KALENG CAT DENGAN METODE CETAK PASIR (SAND CASTING) - 1-11 Ali Rosyidin

2. ANALISA DAN PERANCANGAN SISTEM KENDALI PLC XBC MINI BAS - 12-18 Alim Hardiansyah \& Bambang Suardi Waluyo

3. PENGATUR KESTABILAN SUHU PADA EGG INCUBATOR BERBASIS ARDUINO - 19-22

Abel Putra Hidayah \& Sumardi Sadi

4. METODE PEMBUATAN PONDASI BORE PILE DENGAN KINGPOST DAN METODE PONDASI DINDING PENAHAN TANAH DIAFRAGMA WALL - 23-29

Almufid

5. RANCANG BANGUN SIMULASI PENGENDALI LAMPU LALU LINTAS PADA PERSIMPANGAN DENGAN LIMA JALUR - 30-39

Rahma Farah Ningrum, Puji Catur Siswipraptini, \& Rosida N. Aziza

6. PERANCANGAN PROGRAM APLIKASI PENGENALAN WAJAH DENGAN MENERAPKAN METODE PRINCIPAL COMPONENT ANALYSIS DAN JARINGAN SYARAF TIRUAN - 40-49

M. Lutfi Aksani

7. KAJIAN PENERAPAN SI / TI DALAM MENINGKATKAN KUALITAS PEMBELAJARAN PADA TRAINING CENTER DENGAN MENGGUNAKAN METODOLOGI DeLone And McLean: STUDI KASUS PADA BINUS CENTER JAKARTA - 50-62 Nyoman Ayu Gita Gayatri \& GG Faniru Pakuning Desak

8. RANCANG BANGUN APLIKASI PEMBELAJARAN MATEMATIKA SD KELAS 6 BERBASIS ANDROID PADA SDN CIMONE 1 TANGERANG - 63-69

Winda Anggraeni \& Sri Mulyati

9. RANCANG BANGUN MESIN PERAJANG SINGKONG INDUSTRI RUMAHAN BERDAYA RENDAH - 70-76

Yafid Effendi \& Agus Danang Setiawan

10. RANCANG BANGUN TONGKAT ULTRASONIK UNTUK PENYANDANG TUNA NETRA BERBASIS ARDUINO UNO - 77-82

Bayu Purnomo \& Basuki Isnanto

11. ENTERPRISE RISK MANAGEMENT PADA CLOUD COMPUTING - 83-87

Samudera Dipa Legawa

12. ANALISIS NETWORK PLANNING DENGAN CRITICAL PATH METHOD (CPM) PADA PROYEK UNINTERATUBLE POWER SUPPLY (UPS) 80KVA PADA PT. HARMONI MITRA SUKSES (STUDI KASUS: RSAB HARAPAN KITA, JAKARTA) - 88-97

Hermanto, Novy Fauziah, \& Elfitria Wiratmani 


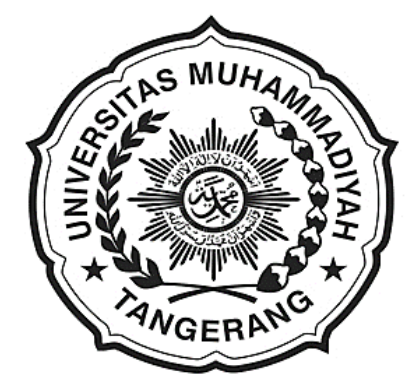

\section{Sambutan Dekan \\ Fakultas Teknik \\ Universitas Muhammadiyah Tangerang}

Puji Syukur kehadirat Allah Swt. karena berkat karunia dan ijin-Nyalah Tim penyusun Jurnal Teknik Fakultas Teknik Universitas Muhammadiyah Tangerang dapat menyelesaikan tugasnya tepat sesuai dengan waktu ditetapkan.

Saya menyambut baik diterbitkannya Jurnal Teknik Vol. 6 No. 1, Januari-Juni 2017, terbitnya jurnal ini, merupakan respon atas terbitnya Peraturan Menteri Pendidikan Nasional No. 17 Tahun 2010 tentang Pencegahan dan Penanggulangan Plagiat di Perguruan Tinggi; Surat Dirjen Dikti Nomor 2050/E/T/2011 tentang kebijakan unggah karya ilmiah dan jurnal; Surat Edaran Dirjen Dikti Nomor 152/E/T/2012 tertanggal 27 Januari 2012 perihal publikasi karya ilmiah yang antara lain menyebutkan untuk lulusan program sarjana terhitung mulai kelulusan setelah 2012 harus menghasilkan makalah yang terbit pada jurnal ilmiah.

Terbitnya Jurnal ini juga diharapkan dapat mendukung komitmen dalam menunjang peningkatan kemampuan para dosen dan mahasiswa dalam menyusun karya ilmiah yang dilandasi oleh kejujuran dan etika akademik. Perhatian sangat tinggi yang telah diberikan rektor Universitas Muhammadiyah Tangerang khususnya mengenai plagiarism dan cara menghindarinya, diharapkan mampu memacu semangat dan motivasi para pengelola jurnal, para dosen dan mahasiswa dalam menyusun karya ilmiah yang semakin berkualitas.

Saya mengucapkan banyak terimakasih kepada para penulis, para pembahas yang memungkinkan jurnal ini dapat diterbitkan, dengan harapan dapat dimanfaatkan seoptimal mungkin dalam peningkatan kualitas karya ilmiah.

Dekan Fakultas Teknik

Universitas Muhammadiyah Tangerang,

\section{Ir. Saiful Haq, M.Si.}




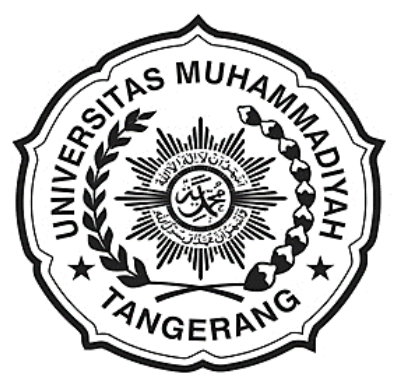

\section{Pengantar Redaksi}

Jurnal Teknik

Universitas Muhammadiyah Tangerang

Puji dan Syukur Alhamdulillah kami panjatkan kehadapan Allah Swt. atas karunia dan lindungan-Nya sehingga Jurnal Teknik Vol. 6 No. 1 edisi Januari-Juni 2017 dapat diterbitkan.

Menghasilkan karya ilmiah merupakan sebuah tuntutan perguruan tinggi di seluruh dunia. Tri Dharma Perguruan Tinggi yaitu darma pendidikan, darma penelitian, dan darma pengabdian kepada masyarakat mendorong lahirnya dinamika intelektual diantaranya menghasilkan karyakarya ilmiah. Penerbitan Jurnal Teknik ini dimaksudkan sebagai media dokumentasi dan informasi ilmiah yang sekiranya dapat membantu para dosen, staf dan mahasiswa dalam menginformasikan atau mempublikasikan hasil penelitian, opini, tulisan dan kajian ilmiah lainnya kepada berbagai komunitas ilmiah.

Buku Jurnal yang sedang Anda pegang ini menerbitkan 12 artikel yang mencakup bidang teknik sebagaimana yang tertulis dalam daftar isi dan terdokumentasi nama dan judul-judul artikel dengan jumlah halaman 1-97 halaman.

Jurnal Teknik ini tentu masih banyak kekurangan dan masih jauh dari harapan, namun demikian tim redaksi berusaha untuk ke depannya menjadi lebih baik dengan dukungan kontribusi dari semua pihak. Harapan Jurnal Teknik akan berkembang menjadi media komunikasi intelektual yang berkualitas, aktual dan faktual sesuai dengan dinamika di lingkungan Universitas Muhammadiyah Tangerang.

Tak lupa pada kesempatan ini kami mengundang pembaca untuk mengirimkan naskah ringkasan penelitiannya ke redaksi kami. Kami sangat berterimakasih kepada semua pihak yang telah membantu penerbitan Jurnal Teknik ini semoga buku yang sedang Anda baca ini dapat bermanfaat.

Pimpinan Redaksi Jurnal Teknik

Universitas Muhammadiyah Tangerang,

Ir. Sumardi Sadi, S.Pd., ST., MT. 


\title{
RANCANG BANGUN SIMULASI PENGENDALI LAMPU LALU LINTAS PADA PERSIMPANGAN DENGAN LIMA JALUR
}

\author{
Rahma Farah Ningrum, Puji Catur Siswipraptini, Rosida N. Aziza \\ Jurusan Teknik Informatika STT-PLN Jakarta \\ Jl. Lingkar Luar, Duri, Kosambi, Cengkareng, Jakarta Barat 11750 \\ E-mail: rahmafarah@sttpln.ac.id
}

\begin{abstract}
The imbalance between the rapid increase in the number of motor vehicles in urban cities in Indonesia and the available transportation infrastructure, such as the capacity of the road, has created more congestions or traffic jams. The congestions that mostly occur at inter-sections or crossroads can cause several problems in terms of time delays, cost, health and environment issues due to air pollution. The traffic jams can be reduced by imposing the right traffic control. One of the solutions to optimize the traffic condition at intersections is by controlling the traffic lights. Each traffic light at an intersection needs to have different set of green and red periods based on the current traffic condition. The purpose of this paper is to simulate the traffic condition at an intersection with 5 lines. The simulation can be used to display the results of the traffic light control possibilities on each line.
\end{abstract}

Keywords: traffic light, traffic control, simulation.

\begin{abstract}
ABSTRAK
Ketidakseimbangan antara nilai pertumbuhan kendaraan bermotor dengan pembangunan infrastruktur jalan raya di kota-kota besar di Indonesia menyebabkan bertambahnya kemacetan lalu lintas. Kemacetan yang umumnya terjadi di persimpangan-persimpangan dapat menyebabkan kerugian, antara lain adanya keterlambatan, biaya bertambah, dan masalah kesehatan serta lingkungan akibat polusi. Kemacetan tersebut dapat dikurangi dengan menerapkan pengaturan lalu lintas yang sesuai. Salah satu cara untuk mengurangi kemacetan di persimpangan adalah dengan mengatur periode lampu lalu lintas sesuai dengan keadaan lalu lintas saat ini. Tujuan dari penulisan ini adalah untuk mensimulasikan kondisi lalu lintas pada persimpangan dengan 5 jalur lalu lintas ( 4 jalur kendaraan +1 jalur busway). Hasil dari simulasi dapat digunakan untuk menampilkan berbagai kemungkinan dari hasil pengaturan lampu lalu lintas pada tiap-tiap jalur.
\end{abstract}

Kata Kunci: lampu lalu lintas, pengaturan lalu lintas, simulasi.

\section{PENDAHULUAN}

Kemacetan banyak dijumpai di kota besar di Indonesia dan hal ini dapat mengganggu manusia dalam menjalankan aktivitas sehari-hari. Manusia dapat mengalami kerugian waktu, biaya, masalah kesehatan akibat kemacetan di jalan raya. Ada beberapa faktor yang dapat menye-babkan kemacetan di jalan raya, antara lain karena ketidakseimbangan antara jumlah kendaraan dengan fasilitas infrastruktur jalan raya yang tersedia dan kurang optimalnya pengendalian lalu lintas di kota besar atau urban traffic control. Bahkan menurut beberapa riset, antara lain dari W. Jatmiko dan kawankawan (Jatmiko, W. et al, 2010) penyebab 
utama kemacetan di kota besar adalah kurang optimalnya pengaturan lalu lintas.

Adanya konflik pergerakan kendaraan pada persimpangan dan tidak optimalnya pengaturan lampu lalu lintas yang terdapat pada persimpangan tersebut merupakan contoh penyebab kemacetan akibat kurangnya pengendalian lalu lintas (traffic control). Lampu lalu lintas yang tersedia di persimpangan jalan mempunyai beberapa tujuan, antara lain untuk menghindari hambatan karena adanya perbedaan arus jalan bagi pergerakan kendaraan, memfasilitasi pejalan kaki agar dapat menyeberang dengan aman, dan mengurangi tingkat kecelakaan yang diakibatkan oleh tabrakan karena perbedaan arus jalan. Karena lampu lalu lintas memegang peranan penting dalam pengaturan lalu lintas di persimpangan, maka dibutuhkan pengendalian dan pengontrolan lampu lalu lintas yang seksama. Masih terdapat lampulampu lalu lintas dengan durasi lampu merah dan durasi lampu hijau yang tidak sesuai dengan kondisi lalu lintas pada suatu saat. Misalkan, jalur jalan dengan kondisi trafik padat diberi durasi lampu hijau yang pendek. Hal ini akan menimbulkan antrian (kendaraan) yang menumpuk sehingga menyebabkan kemacetan.

Beberapa penelitian dilaksanakan untuk meningkatkan mekanisme pengendalian dan pengaturan lalu lintas di kota besar. Salah satunya adalah usulan pengaturan lalu lintas kota besar dengan sistem self-organization berdasar model predictive interval microscopic (B.Placzek, 2014). Dengan sistem selforganization pengaturan lalu lintas tidak dilakukan terpusat oleh suatu unit kendali khusus, melainkan dilakukan melalui interaksi antar agen-agen atau elemen-elemen lalu lintas lokal (bottom-up process). Metode pengendalian lalu lintas dengan sistem self-organization ini juga diajukan oleh Jatmiko dkk (W. Jatmiko et al, 2010). Beberapa penelitian juga dilakukan untuk mengembangkan mekanisme pengaturan lampu lalu lintas yang dapat menyesuaikan keadaan lalu lintas secara real time. Contohnya adalah mekanisme pengendalian lampu lalu lintas berdasarkan panjang antrian dengan metode deteksi tepi dan segmentasi (Priutomo, Magdalena, dan Andini, 2016), metode Travelling Salesman dan Algoritma Greedy (Siswipraptini et al, 2016). Ada pula penelitian mengenai pengendalian lampu lalu lintas menggunakan metode fuzzy logic (Husnaini, 2015).

Adapun perancangan simulasi pengendali lampu lalu lintas pada persimpangan dengan 5 jalur ini didasarkan pada deteksi panjang antrian pada tiap jalur. Aplikasi simulasi ini disusun dalam bentuk project aplikasi pada PC/ Laptop dan output yang dihasilkan diharapkan dapat membantu pihak-pihak terkait melakukan simulasi untuk mendapatkan pengaturan lampu lalu lintas yang akan menghasilkan kondisi lalu lintas lebih baik.

\section{METODOLOGI DAN KERANGKA PEMIKIRAN}

Gambar 1 menunjukkan diagram alir langkah-langkah yang dilaksanakan dalam penelitian ini. Adapun penjelasannya adalah sebagai berikut:

\subsection{Identifikasi Masalah}

Pada tahap awal pengerjaan perancangan ini dilakukan identifikasi masalah dimana pada tahap ini mulai dikaji salah satu penyebab kemacetan di persimpangan, yaitu ketidak-sesuaian antara durasi waktu nyala lampu lalu lintas dengan panjang antrian kendaraan.

\subsection{Kajian Pustaka}

Setelah mengetahui masalah yang akan diteliti, penulis melakukan kajian pustaka mengenai hgal-hal yang berkaitan dengan masalah tersebut sehingga nantinya dalam melakukan penelitian, penulis memiliki pengetahuan dasar yang kuat sehingga dapat menunjang pencarian solusi yang tepat dan lebih terarah dalam pengerjaannya. 


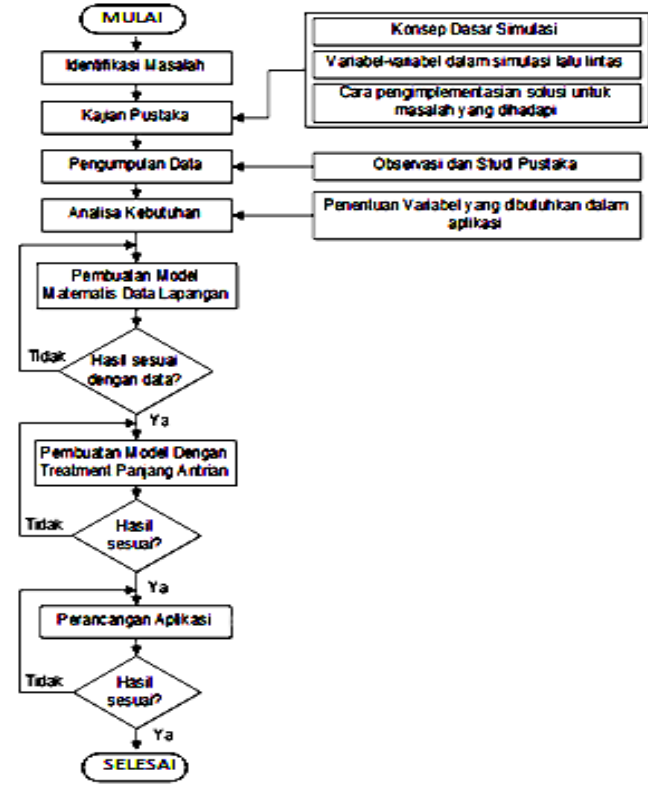

Gambar 1. Kerangka Pemikiran Penelitian.

\subsection{Pengumpulan Data}

Pembuatan rancangan simulasi ini didasarkan pada suatu model matematis yang perumusannya mengacu pada data kendaraan di sebuah perempatan yang dijadikan tempat pengambilan data. Untuk itu perlu dilakukan pengumpulan data sesuai dengan variabel-variabel yang telah ditetap-kan pada tahap sebelumnya, yaitu lama waktu menyala lampu lalu lintas, jumlah kendaraan pada tiap jalur, dan waktu pengamatan. Pengumpulan data dilakukan dengan observasi langsung dan studi pustaka.

\subsection{Analisis Kebutuhan}

Setelah mendapatkan data-data dari hasil observasi, tahap selanjutnya yaitu melakukan analisis kebutuhan variabel yang kiranya dibutuhkan dalam form input sebagai masukan dan variabel yang hendak ditampilkan pada form output sehingga aplikasi ini dapat memberikan informasi atau hasil yang sesuai dengan kebutuhan.

\subsection{Pembuatan Model Matematis Data Lapangan}

Dari data lapangan yang diperoleh sebelumnya, penulis mencoba membuat model matematis yang dapat merepresentasikan keadaan data sesungguhnya di lapangan sehingga nantinya dapat diterapkan dalam aplikasi simulasi yang dirancang. Pembuatan model matematis ini juga didasarkan pada beberapa teori yang diperoleh saat tahap kajian pustaka.

\subsection{Pembuatan Model Lampu Lalu Lintas Berdasar Antrian Per Jalur}

Pada tahap ini akan dilakukan pembuatan model matematis untuk merepresentasikan solusi yang diusulkan sehingga nantinya dapat diimplementasikan dalam aplikasi simulasi ini. Model ini lebih didasarkan pada jumlah kendaraan dalam antrian dan waktu nyala dari masing-masing lampu sehingga hasilnya diharapkan dapat lebih baik dari model sebelumnya.

\subsection{Perancangan Aplikasi}

Pada tahap perancangan aplikasi ini, ada beberapa tahapan yang dilalui mulai dari perancangan antar muka, hierarki menu, pembuatan basis data, koneksi database, implementasi model matematika dan coding.

\section{HASIL PENGAMATAN}

Untuk membantu penyusunan aplikasi ini, dibentuk tim yang mengamati suatu persim-pangan dengan 5 jalur di persimpangan Matraman di Jakarta Timur. Dari pengamatan, dihasilkan beberapa tabel yang berisi informasi mengenai durasi nyala lampu hijau-kuning-merah lampu lalu lintas di persimpangan tersebut, panjang antrian kendaraan, dan kondisi lalu lintas pada waktu-waktu tertentu.

Kolom ruas jalan pada tabel di atas menunjukkan bahwa persimpangan terdiri dari 4 jalan/jalur, yaitu: jalur 1, 2, 3, dan 4 . Jalur 1 dibagi menjadi 2: 1a dan 1b. Jalur 1a merupakan jalur umum, sedangkan jalur $1 \mathrm{~b}$ adalah jalan khusus untuk busway. Masingmasing jalur tersebut dilengkapi dengan lampu lalu lintas. Peneliti memilih waktuwaktu sibuk untuk pengamatan, yaitu pukul 08.00 yang merupakan jam sibuk berangkat kerja, pukul 12.00 waktu sibuk jam istirahat, dan pukul 17.00 yang merupakan waktu sibuk pulang kerja. Diambilnya waktu-waktu sibuk dalam penelitian ini dikarenakan ingin didapatkan data antrian kendaraan yang maksimal. 
Tabel 1. Pengaturan Lampu Lalu Lintas pada Pagi Hari

\begin{tabular}{|l|r|c|c|c|c|}
\hline \multirow{2}{*}{ Keadaan } & \multicolumn{5}{|c|}{ Ruas Jalan } \\
\cline { 2 - 5 } & \multicolumn{3}{|c|}{ 1 } & \multirow{2}{*}{$\mathbf{3}$} & $\mathbf{4}$ \\
\cline { 2 - 6 } & 1a & 1b & & \\
\hline Lampu Merah (detik) & 372 & 240 & 440 & 254 & 325 \\
\hline Lampu Kuning (detik) & 2 & 2 & 2 & 2 & 2 \\
\hline Lampu Hijau (detik) & 60 & 120 & 70 & 84 & 30 \\
\hline Panjang Antrian (m) & 449 & & 148 & 315 & 74 \\
\hline
\end{tabular}

Tabel 2. Pengaturan Lampu Lalu Lintas pada Siang Hari

\begin{tabular}{|l|c|c|c|c|c|}
\hline \multirow{2}{*}{ Keadaan } & \multicolumn{5}{|c|}{ Ruas Jalan } \\
\cline { 2 - 5 } & \multicolumn{2}{|c|}{ 1 } & \multirow{2}{*}{$\mathbf{3}$} & $\mathbf{4}$ \\
\cline { 2 - 6 } & 1a & 1b & & \\
\hline Lampu Merah (detik) & 245 & 338 & 335 & 199 & 327 \\
\hline Lampu Kuning (detik) & 2 & 2 & 2 & 2 & 2 \\
\hline Lampu Hijau (detik) & 107 & 84 & 20 & 155 & 32 \\
\hline Panjang Antrian (m) & 482 & & 241 & 204 & 112 \\
\hline
\end{tabular}

Tabel 1 di atas menunjukkan kondisi lalu lintas pada pagi hari. Pada pukul 08.00 pada jalur umum 1 (1a) didapatkan antrian kendaraan sepanjang $449 \mathrm{~m}$. Antrian ini didapatkan dari mengukur panjang antrian kendaraan saat antrian maksimal, yaitu pada saat waktu hijau pada Jl. Matraman Raya hidup, dan waktu nyala lampu hijaunya adalah sekitar 6 menit. Tabel 2 di bawah menunjukkan kondisi persim-pangan tersebut pada siang hari sekitar pukul 12.00 dan tabel 3 menunjukkan keadaan pada jam sibuk di sore hari, sekitar pukul 17.00.

Tabel 3. Pengaturan Lampu Lalu Lintas pada Sore Hari

\begin{tabular}{|l|c|c|c|c|c|}
\hline \multirow{2}{*}{\multicolumn{1}{|c|}{ Keadaan }} & \multicolumn{5}{c|}{ Ruas Jalan } \\
\cline { 2 - 6 } & \multicolumn{2}{|c|}{ 1 } & $\mathbf{2}$ & $\mathbf{3}$ & $\mathbf{4}$ \\
\cline { 2 - 6 } & 1a & 1b & & & \\
\hline Lama Lampu Merah (detik) & 286 & 278 & 275 & 254 & 325 \\
\hline Lama Lampu Kuning (detik) & 2 & 2 & 2 & 2 & 2 \\
\hline Lama Lampu Hijau (detik) & 63 & 35 & 30 & 84 & 30 \\
\hline Panjang Antrian (m) & 500 & & 160 & 330 & 90 \\
\hline
\end{tabular}

Dari tabel-tabel tersebut diketahui bahwa durasi lampu merah dan lampu hijau pada lampu lalu lintas tersebut tidak seragam pada tiap jalurnya. Durasi lampu hijau menyala juga tidak terkait dengan panjang antrian pada suatu jalur. Ada jalur yang jumlah antriannya panjang tetapi memiliki waktu nyala lampu hijau yang pendek dan sebaliknya.

\section{ANALISIS SISTEM USULAN}

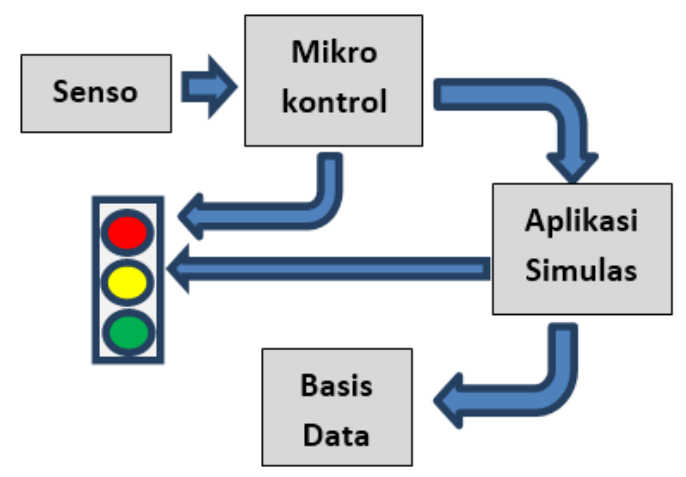

Gambar 2. Blok Sistem Usulan

Aplikasi yang dirancang pada penelitian ini bertujuan untuk melakukan simulasi pengaturan lampu lalu lintas yang tidak statis (dinamis), yaitu durasi lampu hijau menyala pada sistem lalu lintas ini bervariasi ditentukan berdasar panjang antrian kendaraan pada masing-masing jalur. Jika suatu simpang tidak memiliki antrian kendaraan, maka lampu hijau lalu lintas pada simpang tersebut tidak perlu hidup. Jika suatu simpang memiliki panjang antrian yang nantinya berbeda-beda, maka lama nyala lampu hijau-merah pada tiap jalur juga akan berbeda-beda. Jadi, aplikasi ini dibuat untuk mempresentasikan pengendalian yang sedang berlangsung dalam lalu lintas pada suatu persimpangan dengan 5 jalur. Blok diagram sistem pengendalian lampu lalu lintas yang diusulkan ditunjukkan pada gambar 2, namun penulisan ini hanya membahas bagian aplikasi simulasinya. Aplikasi simulasi yang dirancang dapat menunjukkan kinerja dari lampu lalu-lintas yang diatur berdasarkan panjangnya antrian, dengan tujuan dapat memperbaiki sistem berjalan yang belum efektif untuk mengurangi tingkat kemacetan yang meresahkan pengguna jalan. 


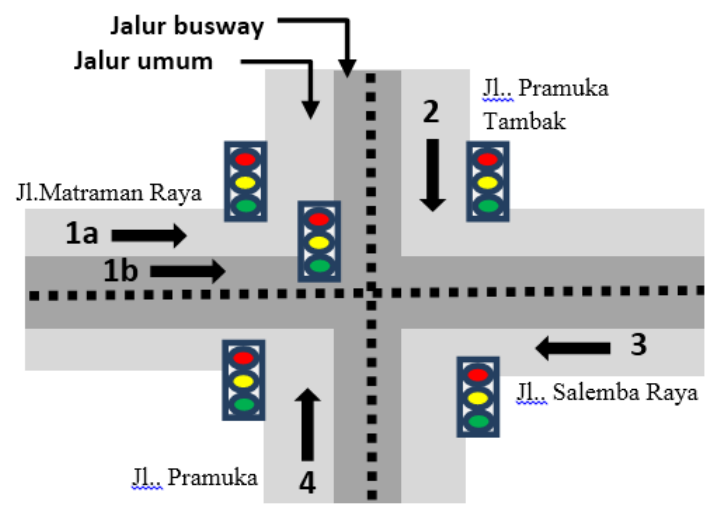

Gambar 3. Gambaran Keadaan Jalan Persimpangan Matraman pada Aplikasi

Nomor-nomor yang diberikan pada gambar hasil penyederhanaan simpang Matraman (Gambar 3) di atas merupakan urutan pergantian lampu lalu lintas yang belaku persimpangan tersebut. Jadi lampu lalu lintas di jalur Jalan Matraman Raya dianggap yang pertama menyala dalam simulasi ini. Hanya pada simpang nomor satu di simpang Matraman yang memiliki lampu lalu lintas jalur busway (1b) terpisah dengan jalur primer atau jalur umum (1a). Sedangkan pada jalur lainnya, lampu lalu lintas untuk jalur busway dan jalur primer disatukan.

Pengaturan durasi waktu nyala lampu lalu lintas di persimpangan tersebut didasarkan pada panjang antrian yang dideteksi /terbaca oleh sensor-sensor inframerah pada aplikasi. Sensor yang disusun pada jalur utama sebanyak lima sensor yang jarak antar sensornya adalah $10 \mathrm{~cm}$, dimana masing $\mathrm{m}$ sing sensor mewakili jarak tertentu seperti yang tertera pada tabel berikut:
Tabel 4. Tabel Keterangan Jarak Sensor

\begin{tabular}{|c|c|c|c|c|}
\hline $\begin{array}{c}\text { Sensor } \\
\text { Nyala }\end{array}$ & $\begin{array}{c}\text { Jarak } \\
\text { pada } \\
\text { simulator }\end{array}$ & $\begin{array}{c}\text { Jarak } \\
\text { Sebenarnya }\end{array}$ & $\begin{array}{c}\text { Level } \\
\text { Sensor }\end{array}$ & $\begin{array}{c}\text { Nyala } \\
\text { Lampu } \\
\text { LED }\end{array}$ \\
\hline- & - & - & $\begin{array}{c}\text { Level } \\
0\end{array}$ & $\begin{array}{c}\text { Lampu } \\
\text { Merah }\end{array}$ \\
\hline $\begin{array}{c}\text { Sensor } \\
1\end{array}$ & $\begin{array}{c}0 \mathrm{~cm}-10 \\
\mathrm{~cm}\end{array}$ & $0 \mathrm{~m}-25 \mathrm{~m}$ & $\begin{array}{c}\text { Level } \\
1\end{array}$ & $\begin{array}{c}\text { Lampu } \\
\text { Hijau } \\
5 \mathrm{~s}\end{array}$ \\
\hline $\begin{array}{c}\text { Sensor } \\
1-2\end{array}$ & $\begin{array}{c}0 \mathrm{~cm}-20 \\
\mathrm{~cm}\end{array}$ & $0 \mathrm{~m}-50 \mathrm{~m}$ & $\begin{array}{c}\text { Level } \\
2\end{array}$ & $\begin{array}{c}\text { Lampu } \\
\text { Hijau } \\
10 \mathrm{~s}\end{array}$ \\
\hline $\begin{array}{c}\text { Sensor } \\
1-3\end{array}$ & $\begin{array}{c}0 \mathrm{~cm}-30 \\
\mathrm{~cm}\end{array}$ & $0 \mathrm{~m}-100 \mathrm{~m}$ & $\begin{array}{c}\text { Level } \\
3\end{array}$ & $\begin{array}{c}\text { Lampu } \\
\text { Hijau } \\
15 \mathrm{~s}\end{array}$ \\
\hline $\begin{array}{c}\text { Sensor } \\
1-4\end{array}$ & $\begin{array}{c}0 \mathrm{~cm}-40 \\
\mathrm{~cm}\end{array}$ & $0 \mathrm{~m}-200 \mathrm{~m}$ & $\begin{array}{c}\text { Level } \\
4\end{array}$ & $\begin{array}{c}\text { Lampu } \\
\text { Hijau } \\
20 \mathrm{~s}\end{array}$ \\
\hline $\begin{array}{c}\text { Sensor } \\
1-5\end{array}$ & $\begin{array}{c}0 \mathrm{~cm}-50 \\
\mathrm{~cm}\end{array}$ & $0 \mathrm{~m}-300 \mathrm{~m}$ & $\begin{array}{c}\text { Level } \\
5\end{array}$ & $\begin{array}{c}\text { Lampu } \\
\text { Hijau } \\
25 \mathrm{~s}\end{array}$ \\
\hline $\begin{array}{c}\text { Sensor } \\
\text { busway } \\
1\end{array}$ & $\begin{array}{c}0 \mathrm{~cm}-10 \\
\mathrm{~cm}\end{array}$ & $0 \mathrm{~m}-25 \mathrm{~m}$ & $\begin{array}{c}\text { Level } \\
1\end{array}$ & $\begin{array}{c}\text { Lampu } \\
\text { Hijau } \\
10 \mathrm{~s}\end{array}$ \\
\hline $\begin{array}{c}\text { Sensor } \\
\text { busway } \\
2\end{array}$ & $\begin{array}{c}0 \mathrm{~cm}-25 \\
\mathrm{~cm}\end{array}$ & $0 \mathrm{~m}-100 \mathrm{~m}$ & $\begin{array}{c}\text { Level } \\
2\end{array}$ & $\begin{array}{c}\text { Lampu } \\
\text { Hijau } \\
20 \mathrm{~s}\end{array}$ \\
\hline
\end{tabular}

Dari tabel di atas dapat dijabarkan bahwa apabila tidak ada sensor yang mendeteksi objek atau menyala, maka disebut level 0 dan lampu merah akan menyala. Jika hanya sensor satu yang menyala. Jika antrian berjarak $0 \mathrm{~cm}$ hingga $10 \mathrm{~cm}$ yang mewakili jarak $0 \mathrm{~m}-25 \mathrm{~m}$, maka disebut level satu dan lampu hijau akan meyala selama 5 detik. Jika yang menyala adalah sensor satu dan sensor dua, antrian pada simulator berjarak 0 $\mathrm{cm}-20 \mathrm{~cm}$, yang mewakili jarak $0 \mathrm{~m}-50$ $\mathrm{m}$ maka lampu hijau akan menyala selama 10 detik. Jika yang menyala adalah sensor satu dan sensor tiga, pada simulator berjarak $0 \mathrm{~cm}-30 \mathrm{~cm}$, yang mewakili jarak $0 \mathrm{~m}-$ $100 \mathrm{~m}$ maka lampu hijau akan menyala selama 15 detik. Jika yang menyala adalah sensor satu dan sensor empat, pada simulator berjarak $0 \mathrm{~cm}-40 \mathrm{~cm}$, yang mewakili jarak $0 \mathrm{~m}-200 \mathrm{~m}$ maka lampu hijau akan menyala selama 20 detik. Jika yang menyala adalah sensor satu dan sensor lima, pada simulator berjarak $0 \mathrm{~cm}-50 \mathrm{~cm}$, yang mewakili jarak $0 \mathrm{~m}-300 \mathrm{~m}$ maka lampu hijau akan menyala selama 25 detik. Khusus pada jalur busway dengan lampu lalu lintas terpisah, apabila yang menyala sensor satu yang berjarak $0 \mathrm{~cm}-10 \mathrm{~cm}$ atau yang mewakili jarak $0 \mathrm{~m}-25 \mathrm{~m}$, merupakan level satu, lampu hijau akan hidup selama 10 detik. Jika pada jalur busway yang 
menyala sensor dua yaitu pada jarak $0 \mathrm{~cm}-$ $25 \mathrm{~cm}$ yang mewakili jarak $0 \mathrm{~m}-100 \mathrm{~m}$ maka akan hidup lampu hijau selama 20 detik.

Aplikasi simulasi yang dirancang dapat menunjukkan kinerja dari lampu lalu - lintas yang diatur berdasarkan panjangnya antrian, dengan tujuan dapat memperbaiki sistem berjalan yang belum efektif untuk mengurangi tingkat kemacetan yang meresahkan pengguna jalan. Output yang ditunjuk-kan dari aplikasi ini adalah penggambaran secara jelas mengenai efisiensi pengaturan lampu lalu lintas yang memperhatikan panjang antrian melalui beberapa variabel seperti: jumlah kendaraan, durasi waktu nyala lampu hijau, dan durasi waktu nyala lampu merah.

\section{PERANCANGAN UML}

\subsection{Use Case Diagram}

Use case diagram adalah pola perilaku sistem yang menggambarkan urutan transaksi yang berhubungan yang dilakukan oleh actor.

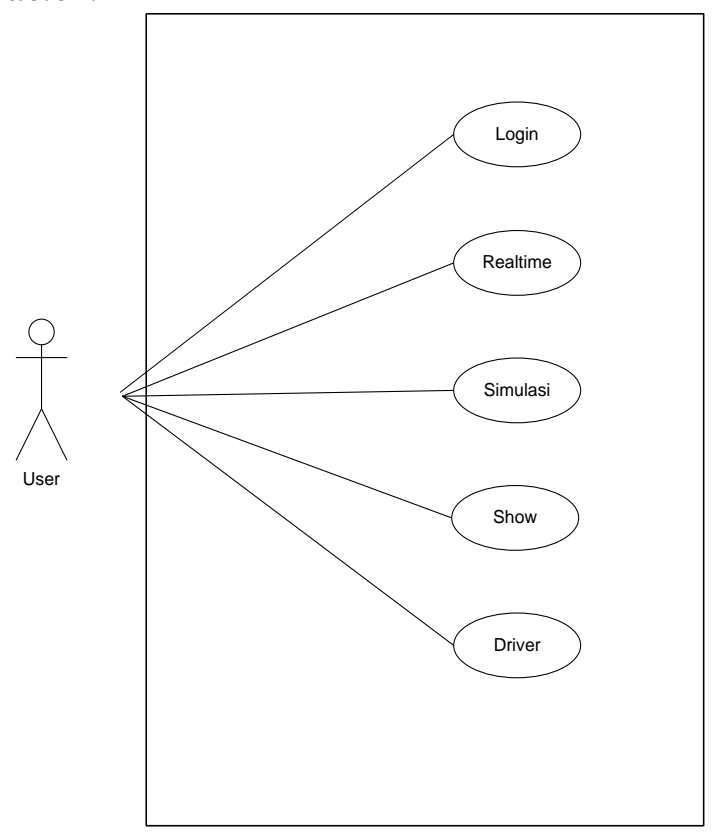

Gambar 4. Use Case Sistem Usulan.

\subsection{Activity Diagram}

Activity diagram menggambarkan proses bisnis dan urutan aktivitas dalam sebuah proses.

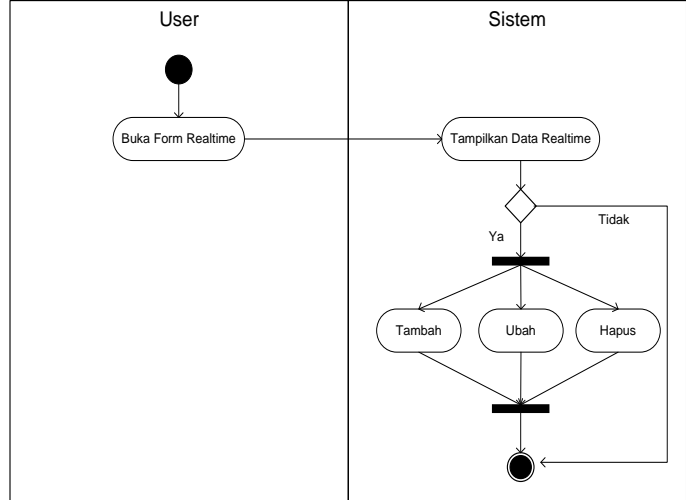

Gambar 5. Activity Diagram Realtime

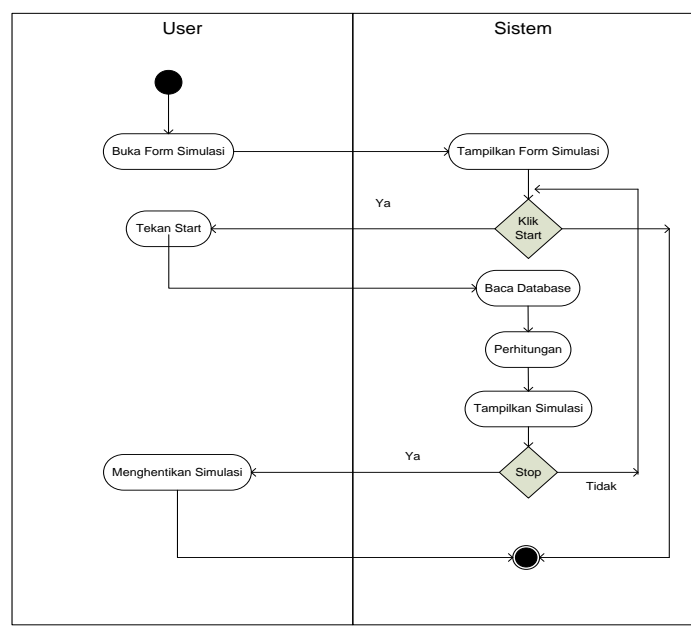

Gambar 6. Activity Diagram Simulasi

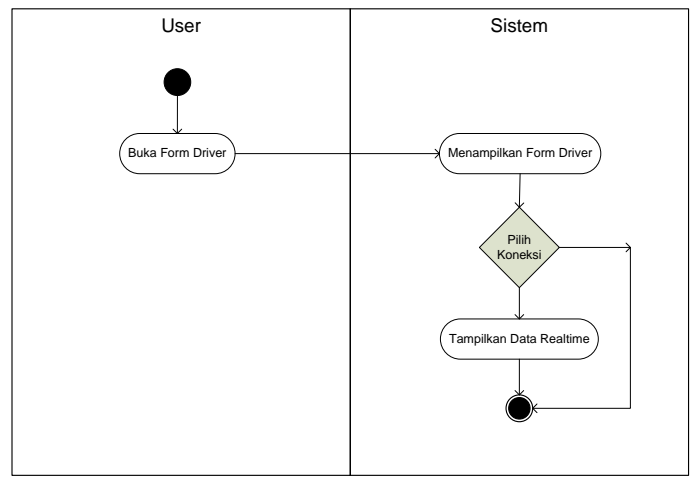

Gambar 7. Activity Diagram Driver

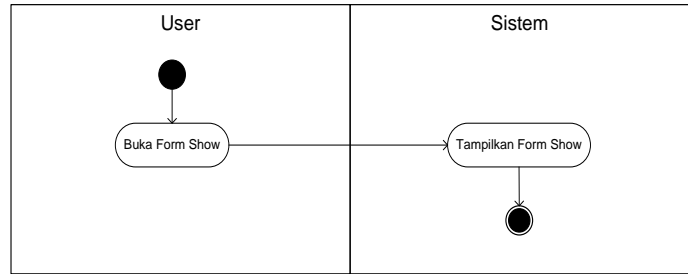

Gambar 8. Activity Diagram Show 
6. HASIL APLIKASI

6.1 Tampilan Form Login

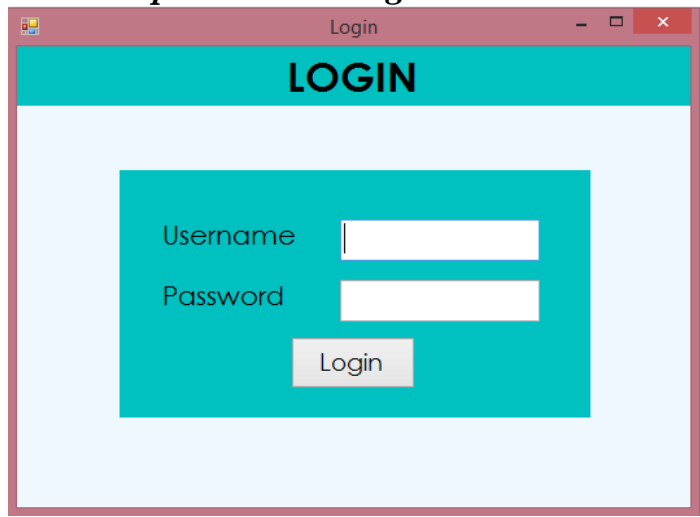

Gambar 9. Tampilan Form Login.

Gambar 9 merupakan tampilan login yang pada awal aplikasi ini dijalankan akan muncul. Pengguna diminta untuk memasukkan username dan password yang telah terdaftar untuk dapat masuk ke aplikasi ini.

\subsection{Tampilan Form Menu Utama}

Gambar 10 merupakan tampilan menu utama yang di dalamnya terdapat 5 tombol menu yaitu: Simulasi, Admin, Realtime, Help, Driver, Show dan Logout. Tombol tombol menu tersebut merupakan akses untuk menggunakan form - form lain yang ada dalam aplikasi ini, serta terdapat pula tombol Logout untuk keluar dari aplikasi ini.

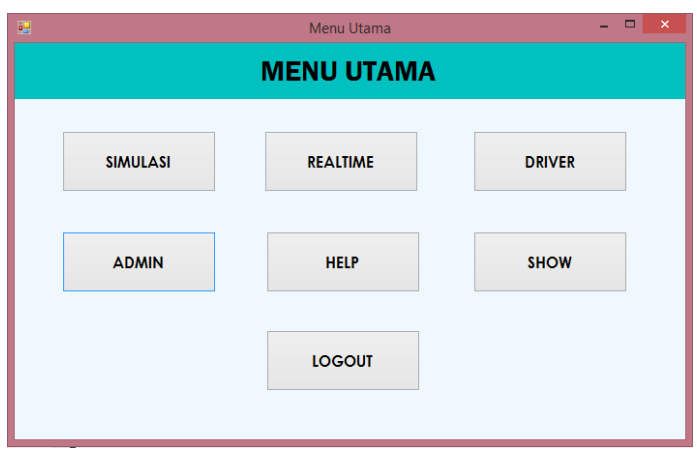

Gambar 10. Tampilan Menu Utama.

\subsection{Tampilan Form Simulasi}

Gambar 11 merupakan tampilan simulasi, dimana simulasi yang dilakukan pada form ini didasarkan dari data yang nantinya diperoleh dari sensor di persimpangan atau bisa juga diatur dari masukan langsung. Pada form ini terdapat dua tombol yaitu: Start dan Close. Tombol Start digunakan untuk mulai menjalankan aplikasi, setelah aplikasi berjalan tombol
Start akan berubah menjadi Stop yang berfungsi untuk menghentikan simulasi yang sedang berjalan. Sedangkan tombol Close digunakan untuk menutup form simulasi dan kembali ke menu utama.

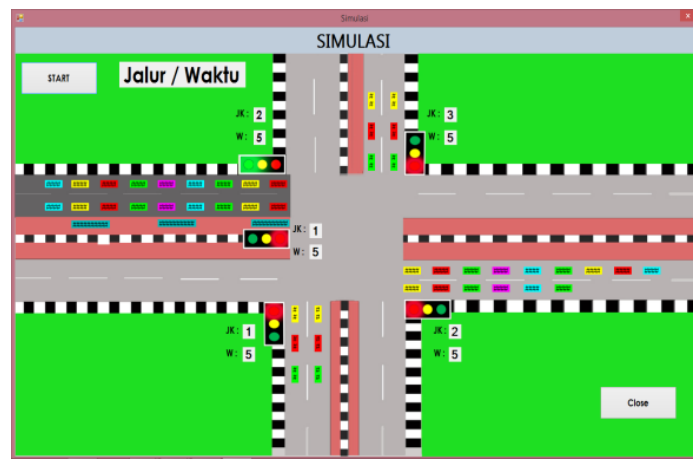

Gambar 11. Tampilan Simulasi

Di bagian atas dari tampilan ini terdapat label Jalur/Waktu. Label tersebut bertujuan untuk menunjukkan jalur mana yang sedang berjalan dan durasi waktu nyala lampu hijau yang diberikan.

Di setiap persimpangan terdapat label jumlah kendaraan dan waktu yang bertujuan untuk menginformasikan berapa jumlah kendaraan yang sedang antri di setiap persimpangan dan berapa durasi waktu nyala lampu hijau dan merah yang diberikan.

\subsection{Tampilan Form Admin}

Gambar 8 merupakan tampilan Admin dimana dalam form ini terdapat data Admin yang telah terdaftar. Pada form ini pengguna dapat menambah, mengubah, dan menghapus data Admin. Pada form ini terdapat beberapa tombol yaitu: Simpan, Ubah, Hapus, Bersih dan Tutup. Penjelasan dari tombol - tombol tersebut adalah sebagai berikut:

1. Simpan: Tombol ini adalah tombol yang digunakan untuk menambahkan data admin. Sebelum menekan tombol ini, pengguna harus terlebih dahulu menginput kode admin, username, password dan status pada input box. Setelah data sudah diinput, lalu tekan tombol ini, maka data akan tersimpan dalam database dan akan tampil di data grid form ini. 


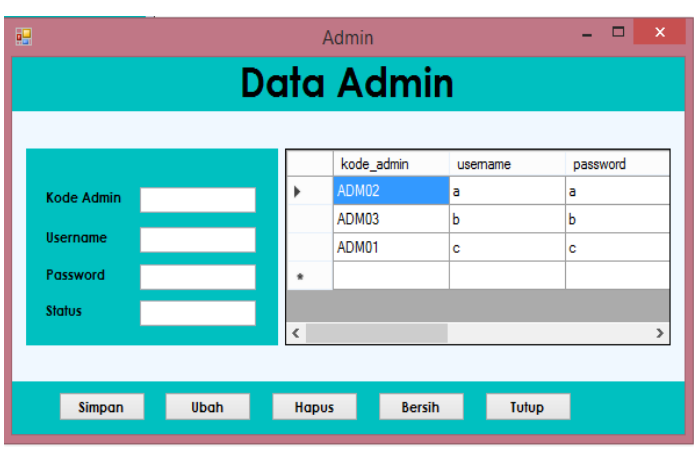

Gambar 12. Tampilan Admin

2. Simpan: Tombol ini adalah tombol yang digunakan untuk menambahkan data admin. Sebelum menekan tombol ini, pengguna harus terlebih dahulu menginput kode admin, username, password dan status pada input box. Setelah data sudah diinput, lalu tekan tombol ini, maka data akan tersimpan dalam database dan akan tampil di Data grid form ini.

3. Ubah: Tombol ini adalah tombol yang digunakan untuk mengubah data admin. Sebelum menekan tombol ini, pengguna harus terlebih dahulu memilih salah satu data yang akan diubah pada data grid, lalu mengubah item yang ingin diubah, baik itu kode admin, username, password atau status pada input box. Setelah data sudah diubah, lalu tekan tombol ini, maka data akan terubah dalam database dan perubahan akan tampil di data grid form ini.

4. Hapus: Tombol ini adalah tombol yang digunakan untuk menghapus data admin. Sebelum menekan tombol ini, pengguna harus terlebih dahulu memilih salah satu data yang akan diubah pada data grid, lalu tekan tombol ini, maka data yang dipilih akan terhapus dari database dan akan berkurang dari tampilan data grid pada form ini.

5. Bersih : Tombol ini adalah tombol yang digunakan untuk membersihkan data pada input box.

6. Tutup : Tombol ini adalah tombol yang digunakan untuk menutup form admin untuk kembali ke menu utama.

\subsection{Tampilan Form Masukan Realtime}

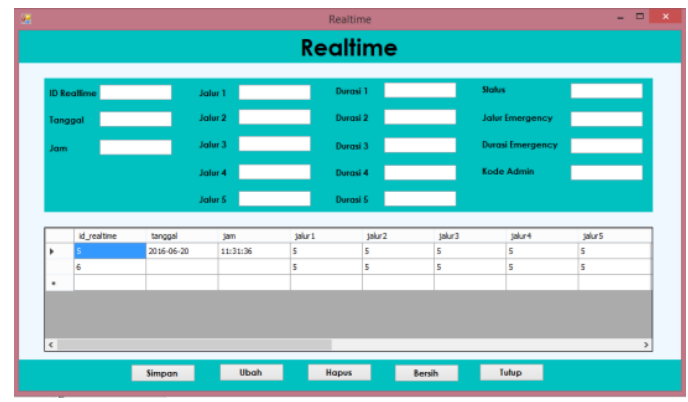

Gambar 13. Tampilan Form Realtime.

Gambar 13 merupakan tampilan masukan realtime dimana dalam form ini terdapat data realtime pada aplikasi. Pada form ini pengguna dapat menambah, mengubah, dan menghapus data realtime.

Pada form ini terdapat beberapa tombol yaitu: Simpan, Ubah, Hapus, Bersih dan Tutup. Penjelasan dari tombol-tombol tersebut adalah sebagai berikut:

1. Simpan: Tombol ini adalah tombol yang digunakan untuk menambahkan data realtime. Sebelum menekan tombol ini, pengguna harus terlebih dahulu menginput data pada input box. Setelah data sudah diinput, lalu tekan tombol ini, maka data akan tersimpan dalam database dan akan tampil di Data grid form ini;

2. Ubah: Tombol ini adalah tombol yang digunakan untuk mengubah data realtime. Sebelum menekan tombol ini, pengguna harus terlebih dahulu memilih salah satu data yang akan diubah pada data grid, lalu mengubah item yang ingin diubah. Setelah data sudah diubah, lalu tekan tombol ini, maka data akan terubah dalam database dan perubahan akan tampil di data grid form ini;

3. Hapus: Tombol ini adalah tombol yang digunakan untuk menghapus data realtime. Sebelum menekan tombol ini, pengguna harus terlebih dahulu memilih salah satu data yang akan diubah pada data grid, lalu tekan tombol ini, maka data yang dipilih akan terhapus dari database dan akan berkurang dari tampilan data grid pada form ini;

4. Bersih: Tombol ini adalah tombol yang digunakan untuk membersihkan data pada input box; dan

5. Tutup: Tombol ini adalah tombol yang digunakan untuk menutup form realtime untuk kembali ke menu utama. 


\subsection{Tampilan Form Help}

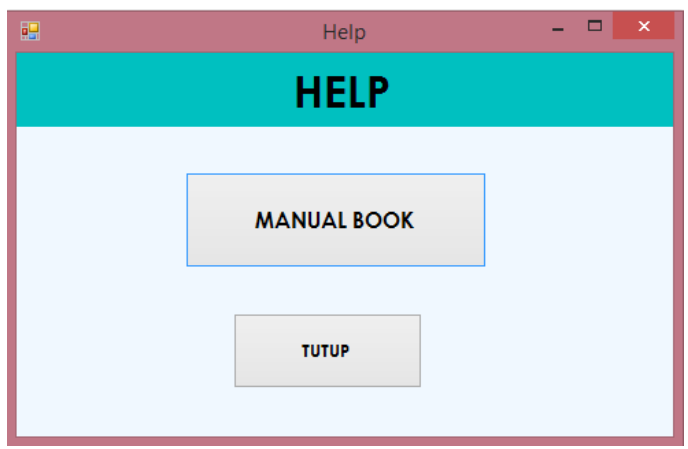

Gambar 14. Tampilan Form Help

Gambar 14 merupakan tampilan help, pada form ini pengguna dapat melihat penjelasan mengenai aplikasi ini hanya dengan menekan tombol manual book. Pada saat tombol manual book ditekan, maka akan terbuka file pdf yang memuat penjelasan tentang aplikasi ini. Sedangkan tombol tutup yang ada di form ini digunakan untuk menutup form dan kembali ke menu utama.

\subsection{Tampilan Form Driver}

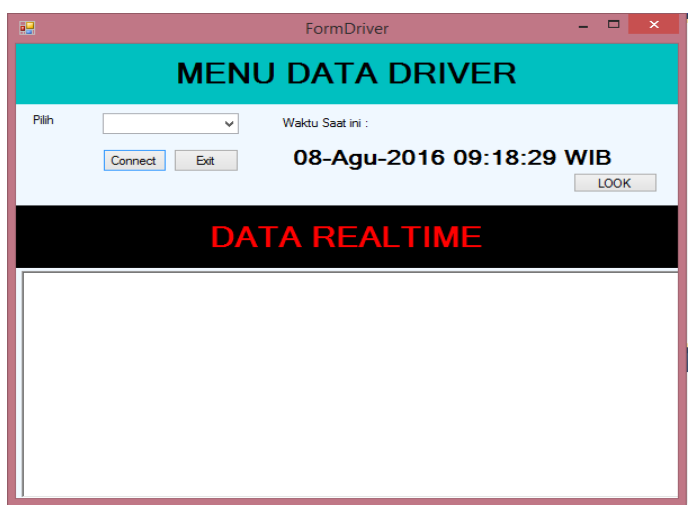

Gambar 15. Form Driver

Gambar 15 merupakan tampilan driver, pada form ini pengguna dapat mengkoneksikan mikrokontroler dengan aplikasi dengan menekan tombol connect, pengguna juga dapat melihat data realtime yang sedang berjalan. Tombol tutup yang ada di form ini digunakan untuk menutup form dan kembali ke menu utama.

\subsection{Tampilan Form Show}

Gambar 16 merupakan tampilan show, pada form ini pengguna dapat melihat history dari data realtime yang telah tersimpan di database. Tombol tutup yang ada di form ini digunakan untuk menutup form dan kembali ke menu utama.

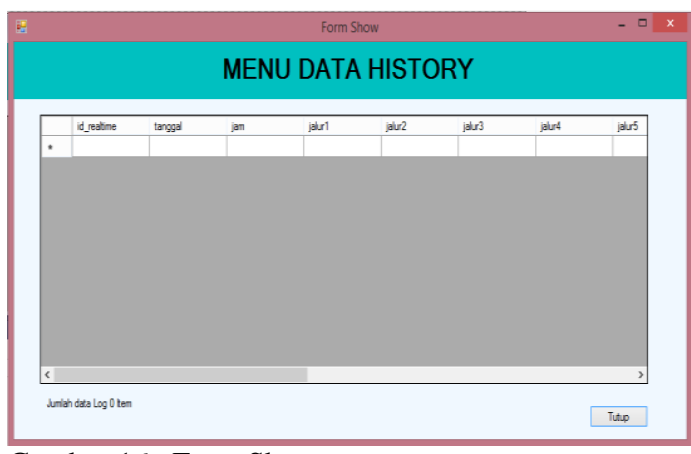

Gambar 16. Form Show

\section{KESIMPULAN}

Kesimpulan yang didapat dari hasil penelitian ini adalah sebagai berikut:

1. Aplikasi Simulasi ini dibuat dengan menggunakan Bahas Pemrograman C\# dan perangkat lunak XAMPP, Microsoft Visual Studio 2010, Edraw Max 6.3.

2. Aplikasi simulasi pengendali lampu lalu lintas ini mengatur durasi lampu merah dan hijau berdasarkan panjang antrian pada tiap jalur pada suatu saat. Jadi, lama lampu lalu lintas tidaklah statis atau tetap, melainkan dinamis, yaitu nyala lampu hijau pada sistem lalu lintas ini berdasarkan panjang antrian kendaraan pada masing-masing simpang. Jika suatu simpang tidak memiliki antrian kendaraan, maka lampu hijau lalu lintas pada simpang tersebut tidak perlu hidup, begitu juga jika suatu simpang memiliki panjang antrian yang nantinya berbeda-beda, maka lama nyala lampu hijau lalu lintas juga nantinya dapat berbeda-beda;

3. Aplikasi ini dirancang dengan memper-hatikan tingkat kepadatan kendaraan di Matraman Jakarta Timur dengan tujuan untuk dapat mengurangi antrian kendaraan di setiap, sehingga dapat mengurangi tingkat kemacetan;

4. Aplikasi ini dirancang dengan lima form utama yaitu form simulasi, form realtime, form help, form driver dan form show; dan

5. Aplikasi simulasi ini telat disiapkan untuk dapat menerima masukan dari mikrokontroler dengan sensor melalui form driver. 


\section{DAFTAR PUSTAKA}

Kalit, Ayu Lestari S.S., Perancangan Simulasi gerakan dan Kendali Antrian pada Smart Traffic Light menggunakan C\# , Jurusan Teknik Informatika, STT-PLN, Jakarta, 2016.

Binus (2012, January). Teori Program C\#. June 23, 2016. http://www.library.binus.ac.id/.../2012-100017-SI\%20Bab2001.html.

Danding Adhi Priutomo, Rita Magdalena, Nur Andini, Simulasi Dan Analisis Sistem Smart Traffic light Berbasis Pengolahan Citra Digital Dengan Metode Deteksi Tepi Dan Segmentasi, Journal of Telkom University. Vol. 3, No. 1 - April 2016. ISSN: 2355-9365, 2016.

Hartanti, D, dan W.H. Martono, Penetapan Titik Pendeteksi Antrian Kendaraan pada Perempatan Lampu Lalu Lintas, Jurnal KILAT, vol.5, No.2, Oktober 2016, ISSN: $2089-1245,2016$.

Irma Husnaini, Rancang Bangun Perangkat Pengendali Lampu Lalu Lintas Menggunakan Logika Fuzzy (Smart Traffic light) Berbasis Mikrokontroler Atmega 8535, Jurnal Universitas Negeri Padang Vol. I, No. 1 - April 2015. ISSN 2302 - 3309, 2015
Jatmiko, W., A.Azurat , HerryA. Wibowo, H. Marihot,M. Wicaksana, I. Takagawa, K. Sekiyama, and T. Fukuda, Self-Organizing Urban Traffic Control Architecture With Swarm Self Organizing Map in Jakarta: Signal Control System and Simulator, International Journal on Smart Sensing and Intelligent Systems, Vo.3, No.\#, September 2010.

Kakiay, Thomas J., Pengantar Sistem Simulasi, Yogyakarta: Andi Yogya, 2003.

Placzek, B., A Self-Organizing System for Urban Traffic Control Based on Predictive Interval Microscopic Model, Engineering Applications of Artificial Intelligence, vol.34, 2014, 75-84.

Siswipraptini, P.C., W.H.Martono, D.Hartanti, New Smart Traffic Light Control using TSP and Greedy Algorithm, The $3^{\text {rd }}$ Asia Future Conference Proceedings, 2016.

Soeparlan, Soepono, Pengantar Simulasi. Jakarta: Gunadarma, 2010.

Sunu Jatmika, Indra Andiko, Simulasi Pengaturan Lampu Lalu Lintas Berdasarkan Data Image Processing Kepadatan Kendaraan Berbasis Mikrokontroler Atmegal6, Jurnal Ilmiah Teknologi dan Informasi ASIA. Vol. 8 No 2 - Agustus 2014. ISSN $1410-8607,2014$ 